\title{
WLBU2 Antimicrobial Peptide as a Potential Therapeutic for Treatment of Resistant Bacterial Infections
}

\section{Dirençli Bakteriyel Enfeksiyonların Tedavisinde Potansiyel Bir Terapötik OlarakWLBU2 Antimikrobiyal Peptit}

\author{
(1) Lina ELSALEM ${ }^{1 *}$, (1) Ayat KHASAWNEH ${ }^{1,2}$, (1) Suhaila AL SHEBOUL 3 \\ 1 Jordan University of Science and Technology Faculty of Medicine, Department of Pharmacology, Irbid, Jordan \\ 2Royal Medical Services, Department of Clinical Pathology and Microbiology, Amman, Jordan \\ 3Jordan University of Science and Technology Faculty of Applied Medical Sciences, Department of Medical Laboratory Sciences, Irbid, Jordan
}

\begin{abstract}
Antimicrobial resistance is considered a major health problem, worldwide. It is significantly associated with high morbidity and mortality rates. The current antibiotics have limited therapeutic efficacy in providing treatment for multidrug resistant bacteria. Accordingly, research in the antimicrobial field has been directed toward the discovery of new agents to overcome bacterial resistance. Antimicrobial peptides (AMP) have been extensively studied as potential antimicrobial agents with lower incidence of drug resistance compared to conventional antibiotics. WLBU2 is an engineered cationic AMP with promising antibacterial activity. It is composed of 24 amino acids including; 13 arginine, 8 valine and 3 tryptophan residues. Findings from in vitro and in vivo studies showed that WLBU2 is a potent peptide with a broad spectrum activity against Gram-positive, Gram-negative, multidrug resistant, and biofilm forming bacteria. Additionally, WLBU2 appears as a salt-resistant peptide with potential application for treatment of infections at conditions with disturbed normal salt homeostasis. Furthermore, WLBU2 was found as AMP with limited host toxicity. Recent investigations have shown that combination of WLBU2 with conventional antibiotics can result in synergism against resistant bacteria. In this review we highlight the evidence supporting the promising properties of WLBU2 as an antibacterial agent with potential applications for the treatment of infections caused by resistant bacteria.
\end{abstract}

Key words: Antimicrobial peptide, WLBU2, resistant bacteria, salt resistant, synergism, combination, non-cytotoxic

öz

Antimikrobiyal direnç, dünya çapında önemli bir sağlık sorunu olarak kabul edilmektedir. Yüksek morbidite ve mortalite oranları ile önemli oranda ilișkilidir. Mevcut antibiyotikler, çoklu ilaca dirençli bakterilerin tedavisini sağlamada sınırlı terapötik etkinliğe sahiptir. Bu nedenle, antimikrobiyal alanda yapılan araştırmalar, bakteriyel direncin ortadan kaldırmak için yeni ajanların keşfedilmesine yöneliktir. Antimikrobiyal peptitler (AMP), geleneksel antibiyotiklere kıyasla daha düșük ilaç direnci insidansına sahip potansiyel antimikrobiyal ajanlar olarak kapsamlı bir şekilde incelenmiștir. WLBU2, umut verici antibakteriyel aktiviteye sahip, tasarlanmıș bir katyonik AMP'dir. On üç arjinin, 8 valin ve 3 triptofan rezidülerini içeren 24 amino asitten meydana gelmektedir. In vitro ve in vivo çalışmalardan elde edilen bulgular, WLBU2'nin Gram-pozitif, Gram-negatif, çoklu ilaç direnci ve biyofilm olușturan bakterilere karşı geniș spektrumlu aktiviteye sahip güçlü bir peptit olduğunu göstermektedir. Ayrıca, WLBU2, normal tuz homeostazı bozulmuş koşullarda enfeksiyonların tedavisi için potansiyel uygulamayla tuza dirençli bir peptit olarak görünmektedir. Dahası, WLBU2 sınırlı konakçı toksisitesine sahip AMP olarak bulunmuştur. Son araştırmalar, WLBU2'nin geleneksel antibiyotiklerle kombinasyonunun dirençli bakterilere karşı sinerjizm ile sonuçlanabileceğini göstermiştir. Bu derlemede, dirençli bakterilerin neden olduğu enfeksiyonların tedavisi için potansiyel uygulamaları olan bir antibakteriyel ajan olarak WLBU2'nin umut verici özelliklerini destekleyen kanıtları vurguluyoruz.

Anahtar kelimeler: Antimikrobiyal peptit, WLBU2, dirençli bakteri, tuza dirençli, sinerjizm, kombinasyon, non-sitotoksik 


\section{INTRODUCTION}

Antimicrobial resistance (AMR) is recognized as a major global threat of negative impact on the public health systems around the world. AMR has reached an alarming level since it is significantly associated with high morbidity and mortality rates. ${ }^{2}$ According to the 2019 Antibiotic Resistance Threats report published by the United States Centers for Disease Control and Prevention, more than 2.8 million antibiotic-resistant infections occur in the U.S. each year, and more than 35,000 people die. ${ }^{3}$ Indeed, the World Health Organization and the United Nations, Interagency Coordination Group on AMR have described the global impact of AMR as being very critical causing more than 700,000 deaths around the world, with expectations to reach 10 million at the end of $2050 .{ }^{4}$ AMR is also well recognized to be associated with increasing healthcare cost. ${ }^{5}$ This is mainly due to the need for expensive antibiotics and prolonged hospitalization and isolation of affected patients. ${ }^{2,6}$

Among Gram-positive pathogens, resistant Staphylococcus aureus has been described as the biggest threat. ${ }^{7}$ Methicillinresistant $S$. aureus (MRSA), known as being resistant to penicillin-like beta-lactam antibiotics, first emerged 6 decades ago. ${ }^{8}$ After that, MRSA infections have rapidly spread around the world, with high incidence were reported in many countries in Europe, USA, UK and the Asia-Pacific region. ${ }^{9}$ Previous studies reported that most MRSA strains were inhibited by vancomycin at minimum inhibitory concentration (MIC) values of 0.125 to $1 \mu \mathrm{g} / \mathrm{mL} .^{10}$ However, increased resistance of certain strains of S. aureus toward vancomycin have been observed." This was first reported in Japan in 1996, with the discovery of clinical isolate with reduced susceptibility to vanocmycin (MIC: $8 \mu \mathrm{g} / \mathrm{mL}$ ), and was called vancomycin intermediate $S$. aureus. ${ }^{12}$ In 2002, the U.S. reported the first S. aureus isolate with complete resistance to vancomycin (MIC $\geq 32 \mu \mathrm{g} / \mathrm{mL}$ ) and was called vancomycin-resistant $S$. aureus..$^{13}$

Currently, substantial evidence points to the negative impact of Gram-negative pathogens, which are considered very common in the community.,14 Indeed, many of these were reported as being multidrug-resistant (MDR) including extended spectrum beta-lactamase-producing Escherichia coli, Neisseria gonorrhoeae and Enterobacter cloacae, ${ }^{3,14-16}$ which are resistant to third generation cephalosporins (ceftriaxone and ceftazidime) and monobactams. ${ }^{17}$

Recognizing the fact that the current antibiotics have limited therapeutic efficacy in providing treatment for MDR Grampositive and negative bacteria, new strategies have been developed to overcome antibiotic bacterial resistance. ${ }^{6}$ Antimicrobial peptides (AMPs) have been extensively studied as potential antimicrobial agents with lower incidence of drug resistance compared to conventional antibiotics. ${ }^{18-20}$ In this review we highlight the evidence of antibacterial activity of WLBU2 peptide as a novel engineered cationic antimicrobial agent with potential applications for treatment of infections caused by resistant bacteria.

\section{Antimicrobial peptides}

AMPs are a large family of low molecular weight peptides that play a key role in innate immunity. Most AMPs are cationic peptides and can kill and/or inhibit bacterial growth. ${ }^{21}$ The exact mechanism of AMP antibacterial effect is not understood. However, AMPs have been suggested to bind the bacterial cell membrane and cause disruption of the lipid components. ${ }^{22}$ This is usually induced by electrostatic interactions between positively charged amino acids within the peptide and negatively charged lipids in bacterial cell membrane. ${ }^{23,24}$ As a consequence, increasing the plasma membrane permeability and disruption of the plasma membrane will cause leakage of ions and metabolites as well as cessation of membrane-coupled respiration and biosynthesis that can contribute to bacterial cell death. ${ }^{23,24}$

\section{WLBU2 antibacterial activity}

WLBU2 is an engineered cationic peptide that contains 24 amino acids including; 13 arginine. Eight valine and 3 tryptophan residues in the hydrophobic face separated from each other by at least 7 amino acids (Figure 1). ${ }^{25}$ Results from in vitro and in vivo investigations revealed the potency of WLBU2 with broad spectrum activity against different types of microorganisms including bacteria and diverse Candida species. ${ }^{26-32}$ Preclinical studies on Pseudomonas aeruginosa described WLBU2 as salt resistant peptide with potent inhibitory effects against bacterial growth and biofilm formation. ${ }^{26,33,34}$ Further investigations on lung infections caused by $P$. aeruginosa supported the antibacterial effects of WLBU2 as well as induction of protective proinflammatory responses upon treatment. ${ }^{33,35}$ The antibacterial potency of WLBU2 was also reported against three oral microorganisms (Streptococcus gordonii, Fusobacterium nucleatum, and Porphyromonas gingivalis). ${ }^{27}$ Additionally, WLBU2 was found to have bactericidal activity against three highly pathogenic bacteria: Francisella tularensis, Yersinia pestis and Burkholderia pseudomallei. ${ }^{28}$ Recently, WLBU2 eliminates pneumonia and MRSA superinfection during influenza and

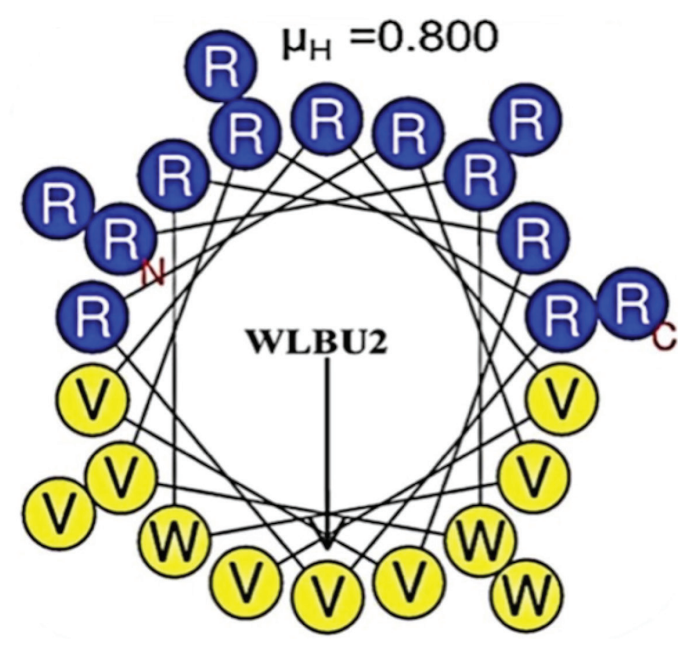

Figure 1. WLBU2 peptide structure. WLBU2 contains 24 amino acids including; 13 arginine (R). Eight valine (V) and 3 tryptophan (W) residues in the hydrophobic face separated from each other by at least 7 amino acids Adopted from Deslouches et al. ${ }^{36}$ license number 4927790008448. 
antibiotic resistant surgical implant biofilms caused by Staphylococcus aureus and MRSA..$^{29,37}$ Additionally, it has been found to be very effective in preventing Enterococcus faecium, Staphylococcus aureus, Klebsiella pneumoniae, Acinetobacter baumannii, P. aeruginosa, E. cloacae (ESKAPE) pathogens' biofilm formation and attachment. ${ }^{30}$ Recent results have revealed potent antibacterial effects against biofilms of MDR $A$. baumannii and K. pneumoniae. ${ }^{31}$

The values of MIC and minimum bactericidal concentrations (MBC) of WLBU2 from previous investigations showed that WLBU2 has fast killing effects on bacterial cells with MIC values $\leq 10 \mu \mathrm{M}^{19,31,36}$ The MIC values of WLBU2 from previous reports were as 1.5-3.2 $\mu \mathrm{M}$ for extensively drug-resistant (XDR) A. baumannii, 2.9-4.7 $\mu \mathrm{M}$ for XDR K. pneumoniae, and $9.3 \mu \mathrm{M}$ for K. pneumoniae KP2 strain. ${ }^{19}$ Additionally, Deslouches et al. ${ }^{36}$ have shown that the MIC values of WLBU2 were $\leq 10 \mu \mathrm{M}$ against both Gram-negative and Gram-positive bacteria including MRSA, vancomycin-resistant enterococci, K. pneumoniae, E. aerogenes, E. cloacae, Escherichia coli, P. aeruginosa, and A. baumannii. Recent investigations found that the MIC was 7.943 $\mu \mathrm{M}$ for K. pneumoniae and $7.484 \mu \mathrm{M}$ for A. baumannii clinical isolates. ${ }^{31}$ Of note, the MBC values for WLBU2 against previous bacterial isolates were found to be identical to the MIC values of respective bacteria, indicating that WLBU2 is bactericidal. ${ }^{38}$

The exact mechanisms for the antimicrobial effect of WLBU2 are yet to be elucidated. However, it was suggested to be mediated by electrostatic interactions between peptide' cationic amino acid residues and the negatively charged lipid molecules on the surface of bacterial targets. ${ }^{26}$ The potent activity of WLBU2 may be attributed to the high cationic charge and the increased length of amino acids of WLBU2 (24 residues). ${ }^{26}$ Previous studies reported that the antibacterial activity of cationic AMP might also be mediated by binding to bacterial DNA. ${ }^{39}$ However, limited investigations have been conducted in this regard for WLBU2. Only recent findings have revealed that WLBU2 at up to the tested $200 \mu \mathrm{M}$ could not delay DNA mobility. ${ }^{31}$

\section{WLBU2 and host cell toxicity}

WLBU2 has been considered potent AMP without significant host cell toxicity. ${ }^{31} \mathrm{~A}$ previous study showed that WLBU2 had no cytotoxic effect at concentration of $\leq 20 \mu \mathrm{M}$ against peripheral blood mononuclear cells, upon testing with the hemolytic assay and MTT assay. ${ }^{19}$ A recent study has also revealed that WLBU2 is not cytotoxic when evaluated against human skin fibroblasts. ${ }^{31}$ The selective toxicity of WLBU2 against bacteria and low toxicity against host cells suggest that WLBU2 form weak interactions with eukaryotic membranes which are highly rich with cholesterol. In comparison, WLBU2 might form robust electrostatic interactions with the negatively charged bacterial membranes. ${ }^{40}$

\section{WLBU2 as salt-resistant peptide}

One of the major drawbacks with the use of AMPs, mainly the natural AMPs, is their limited antibacterial activity due to inactivation by physiological concentrations of salts including sodium chloride and divalent cations. ${ }^{39}$ It has been shown that the antibacterial activity of well-studied natural AMPs (such as LL-37, human $\beta$-defensin-1, gramicidins, bactenecins, and magainins) was substantially reduced under salt conditions. ${ }^{41}$ Turner et al. ${ }^{42}$ showed that MIC values of LL-37 and human neutrophil peptide-1 were significantly increased when $\mathrm{NaCl}$ was added. In comparison, Mohamed et al..$^{39}$ described engineered AMP, RRIKA and RR, as salt-resistant since their antibacterial activity against MRSA was retained in the presence of physiological concentrations of $\mathrm{NaCl}$ and $\mathrm{MgCl}_{2}$. Recent studies also have shown that the synthetic AMPs such as D-RR4 and Hp1404 are salt resistant with retained activity against Gram-negative bacteria including $P$. aeruginosa and $A$. baumannii. ${ }^{43,44}$ WLBU2 appeared as salt resistant since it retained the antibacterial activity when tested in different concentrations of $\mathrm{NaCl}, \mathrm{CaCl}_{2}$ and $\mathrm{MgCl}_{2}$ against Gram-negative P. aeruginosa or Grampositive MRSA strains. ${ }^{26}$ This is considered highly important for the treatment of infections in conditions with disturbed normal salt homeostasis. ${ }^{26}$ The ability of WLBU2 to resist the effects of salts suggests that the chemical structure of WLBU2 has been well designed to relatively retain antimicrobial activity in the presence of $\mathrm{NaCl}$ and divalent cations concentrations that is considered a major challenge for natural peptides. Additionally, it provides a selective advantage as potential therapeutics in physiological solutions. However, further studies are needed to provide more evidence for WLBU2 as a salt-resistant peptide since salt sensitivity might be sometimes dependent on the test organism. ${ }^{26}$

\section{WLBU2 and synergism effects with conventional antibiotics}

Recently, the effects of synthetic AMPs in combination with conventional antibiotics have been investigated against many Gram-negative and Gram-positive bacteria including MDR strains with biofilm formation ability. ${ }^{45-48}$ Studies showed the efficacy of using synthetic peptides in combination with conventional antibiotics to augment the treatment of murine cutaneous abscesses caused by difficult to treat pathogens including all ESKAPE and E. coli. ${ }^{49} \mathrm{Gopal}$ et al..$^{50}$ also reported that synergism was obtained upon combination of conventional antibiotics (cefotaxime, ciprofloxacin, or erythromycin) with four cationic AMP (HPME, HPMA, CAME and CA) against 19 MDR $A$. baumannii isolates. ${ }^{50}$ In addition, synergistic effects were observed upon combination of the AMP DP7 and antibiotics (gentamicin, vancomycin, azithromycin, and amoxicillin) against several MDR bacterial strains including $S$. aureus, P. aeruginosa, A. baumannii, and E. coli. ${ }^{51}$ SPR741 peptide also potentiated the effect of conventional antibiotics against E. coli, K. pneumoniae, and A. baumannii. ${ }^{52}$ Recent findings from combination treatment have shown that T3 and T4 AMP resulted in potentiation of ampicillin and oxacillin against MRSA clinical isolates ${ }^{48} \mathrm{~A}$ synthetic cationic peptide, pexiganan, is currently in phase 3 clinical trials as a contemporary antimicrobial agent for the treatment of E. coli, K. pneumoniae, Citrobacter koseri, E. cloacae, $A$. species, and $P$. aeruginosa infections associated with diabetic foot ulcers. ${ }^{53}$

Upon reviewing the literature, limited evidence is available regarding the combination of WLBU2 and other conventional 
antibiotics. Only a recent study has revealed that combination of sub-inhibitory concentrations of WLBU2 with amoxicillinclavulanate or ciprofloxacin for $K$. pneumoniae, and with tobramycin or imipenem for $A$. baumannii, resulted in synergism with significant reduction in MIC values for some investigated isolates and ATCC strains. ${ }^{31}$ Synergism and potentiation upon a combination of WLBU2 and conventional antibiotics might result from increased membrane permeability caused by the action of WLBU2 cationic peptide, which enhanced the penetration of antibiotics toward bacterial cells and thus, improved the drug efficacy and killing effects. ${ }^{45,54}$ Further, it might result in obtaining synergistic effects and thus enhances efficacy. ${ }^{54}$ Advantages of combination treatment may also include broadening the spectrum of antimicrobial coverage and reducing the needed doses of each antimicrobial agent and thus, drug toxicity. ${ }^{54}$ However, future studies are needed to explore the potential of using WLBU2 along with conventional antibiotics against other MDR and biofilm forming bacteria.

Cationic AMP are emerging as potential antimicrobial agents that can be used as alternative or complement to conventional antibiotics to overcome drug-resistant infections. WLBU2 appears as a novel peptide with promising properties summarized in (Figure 2).

\section{CONCLUSION}

In vitro and in vivo studies showed that WLBU2 is potent antimicrobial agent with bactericidal effects and broad spectrum activity against many Gram-positive, Gram-negative, multidrug resistant, and biofilm forming bacteria. The therapeutic potential of AMPs can be affected by physiological conditions including

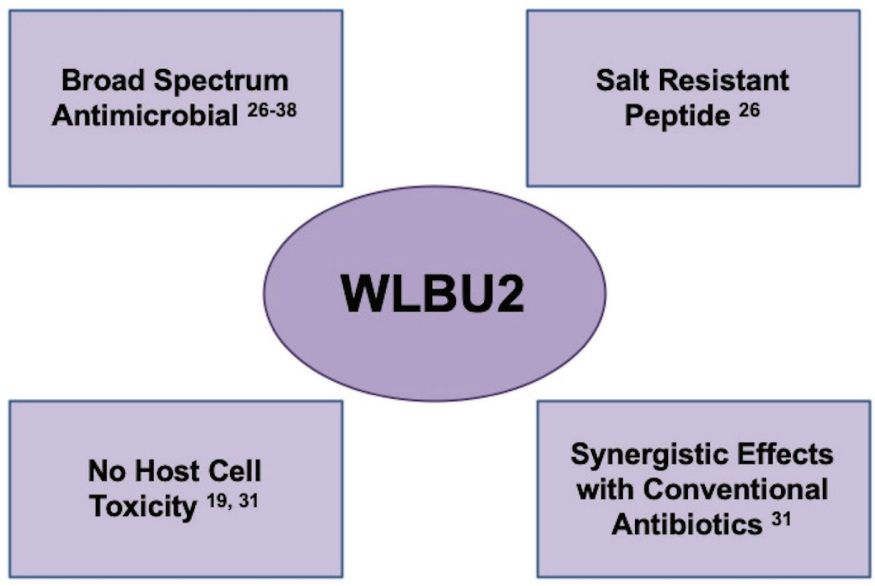

Figure 2. Properties of WLBU2 antimicrobial peptide

the presence of salts and divalent cations at infection site or body fluids. WLBU2 showed the ability to resist the effects of salts which provides a selective advantage as potential therapeutics in physiological solutions and suggests that WLBU2 has been successfully synthetized to resist different salts types and concentrations, that is considered a major drawback of natural AMPs. WLBU2 also appears as AMP with minimal cytotoxic effects against host cells Recent studies have provided proof of concept that WLBU2 as a cationic AMP can be used in combination with conventional antibiotics to reduce antimicrobial drug resistance which is considered a major issue to any health care system.

Future studies on the ability of WLBU2, either alone or along with conventional antibiotics, to eradicate or prevent biofilm formation will increase our knowledge regarding WLBU2 antibacterial activity. This might be considered under normal conditions and in the presence of salts, serum and proteases. Limited evidence is available regarding the potential synergism between WLBU2 and other cationic AMPs and therefore, it might be considered for future studies. Additionally, in vivo animal studies evaluating WLBU2 antibacterial activity as potential peptide for treatment of bacterial infections might be highly valuable to be carried in the future. Similar investigations could be conducted for many MDR Gram-positive and Gram-negative bacteria to characterize the spectrum of WLBU2 activity which is expected to be broad spectrum.

Investigations regarding the exact underlying mechanisms of the antibacterial activity of WLBU2 alone and combined with conventional antibiotics might be considered future experiments, since the underlying mechanisms are still to be elucidated. These investigations might involve studies on morphological changes or effects at the molecular level including genes playing role in bacterial resistance or bacterial metabolism as well as other energetics aspects.

Conflict of interest: No conflict of interest was declared by the authors. The authors alone are responsible for the content and writing of this article.

\section{REFERENCES}

1. Ferri M, Ranucci E, Romagnoli P, Giaccone V. Antimicrobial resistance: A global emerging threat to public health systems. Crit Rev Food Sci Nutr. 2017;57:2857-2876.

2. Prestinaci F, Pezzotti P, Pantosti A. Antimicrobial resistance: a global multifaceted phenomenon. Pathog Glob Health. 2015;109:309-318.

3. https://www.cdc.gov/drugresistance/pdf/threats-report/2019-arthreats-report-508.pdf

4. No Time to Wait: Securing the future from drug-resistant infections. UN Interagency Coordination Group (IACG) on Antimicrobial Resistance, 2019.

5. Dadgostar P. Antimicrobial resistance: implications and costs. Infect Drug Resist. 2019;12:3903-3910.

6. Thabit AK, Crandon JL, Nicolau DP. Antimicrobial resistance: impact on clinical and economic outcomes and the need for new antimicrobials. Expert Opin Pharmacother. 2015;16:159-177.

7. Gajdács M. The continuing threat of methicillin-resistant Staphylococcus aureus. Antibiotics (Basel). 2019;8:52.

8. Harkins CP, Pichon B, Doumith M, Parkhill J, Westh H, Tomasz A, de Lencastre H, Bentley SD, Kearns AM, Holden MTG. Methicillinresistant Staphylococcus aureus emerged long before the introduction of methicillin into clinical practice. Genome Biol. 2017;18:130.

9. Mutters NT, Günther F, Sander A, Mischnik A, Frank U. Influx of multidrug-resistant organisms by country-to-country transfer of patients. BMC Infect Dis. 2015;15:466. 
10. Kshetry AO, Pant ND, Bhandari R, Khatri S, Shrestha KL, Upadhaya SK, Poudel A, Lekhak B, Raghubanshi BR. Minimum inhibitory concentration of vancomycin to methicillin resistant Staphylococcus aureus isolated from different clinical samples at a tertiary care hospital in Nepal. Antimicrob Resist Infect Control. 2016;5:27.

11. McGuinness WA, Malachowa N, DeLeo FR. Vancomycin resistance in Staphylococcus aureus. Yale J Biol Med. 2017;90:269-281.

12. Perl TM. The threat of vancomycin resistance. Am J Med. 1999;106:26S-37S; discussion 48S-52S.

13. Centers for Disease Control and Prevention (CDC). Staphylococcus aureus resistant to vancomycin--United States, 2002. MMWR Morb Mortal Wkly Rep. 2002;51:565-567.

14. Exner M, Bhattacharya S, Christiansen B, Gebel J, Goroncy-Bermes P, Hartemann P, Heeg P, Ilschner C, Kramer A, Larson E, Merkens W, Mielke M, Oltmanns P, Ross B, Rotter M, Schmithausen RM, Sonntag HG, Trautmann M. Antibiotic resistance: what is so special about multidrug-resistant Gram-negative bacteria? GMS Hyg Infect Control. 2017;12:Doc05.

15. Kaye KS, Pogue JM. Infections caused by resistant Gram-negative bacteria: epidemiology and management. Pharmacotherapy. 2015;35:949-962.

16. Ventola CL. The antibiotic resistance crisis: part 1: causes and threats. P T. 2015;40:277-283.

17. Coque TM, Baquero F, Canton R. Increasing prevalence of ESBLproducing Enterobacteriaceae in Europe. Euro Surveill. 2008;13:19044. Erratum in: Euro Surveill. 2008;13.

18. Peschel A, Sahl HG. The co-evolution of host cationic antimicrobial peptides and microbial resistance. Nat Rev Microbiol. 2006;4:529-536.

19. Deslouches B, Steckbeck JD, Craigo JK, Doi Y, Mietzner TA, Montelaro RC. Rational design of engineered cationic antimicrobial peptides consisting exclusively of arginine and tryptophan, and their activity against multidrug-resistant pathogens. Antimicrob Agents Chemother 2013;57:2511-2521.

20. Sinha R, Shukla P. Antimicrobial peptides: recent insights on biotechnological interventions and future perspectives. Protein Pept Lett. 2019;26:79-87.

21. Zhu X, Dong N, Wang Z, Ma Z, Zhang L, Ma Q, Shan A. Design of imperfectly amphipathic $\alpha$-helical antimicrobial peptides with enhanced cell selectivity. Acta Biomater. 2014;10:244-257.

22. Sani MA, Separovic F. How membrane-active peptides get into lipid membranes. Acc Chem Res. 2016;49:1130-1138.

23. Schmidt NW, Wong GC. Antimicrobial peptides and induced membrane curvature: geometry, coordination chemistry, and molecular engineering. Curr Opin Solid State Mater Sci. 2013;17:151-163.

24. Li J, Koh JJ, Liu S, Lakshminarayanan R, Verma CS, Beuerman RW. Membrane active antimicrobial peptides: translating mechanistic insights to design. Front Neurosci. 2017;11:73.

25. Deslouches B, Phadke SM, Lazarevic V, Cascio M, Islam K, Montelaro RC, Mietzner TA. De novo generation of cationic antimicrobial peptides: influence of length and tryptophan substitution on antimicrobial activity. Antimicrob Agents Chemother. 2005;49:316-322.

26. Deslouches B, Islam K, Craigo JK, Paranjape SM, Montelaro RC Mietzner TA. Activity of the de novo engineered antimicrobial peptide WLBU2 against Pseudomonas aeruginosa in human serum and whole blood: implications for systemic applications. Antimicrob Agents Chemother. 2005:49:3208-3216.

27. Novak KF, Diamond WJ, Kirakodu S, Peyyala R, Anderson KW, Montelaro RC, Mietzner TA. Efficacy of the de novo-derived antimicrobial peptide WLBU2 against oral bacteria. Antimicrob Agents Chemother. 2007:51:1837-1839.

28. Abdelbaqi S, Deslouches B, Steckbeck J, Montelaro R, Reed DS. Novel engineered cationic antimicrobial peptides display broad-spectrum activity against Francisella tularensis, Yersinia pestis and Burkholderia pseudomallei. J Med Microbiol. 2016;65:188-194.

29. Rich H, Deslouches B, McHugh KJ, Montelaro R, Robinson KM, Alcorn JF. The synthetic antimicrobial peptide WLBU2 promotes Staphylococcus aureus clearance in the mouse lung. Am J Respir Crit Care Med 2016;A6727.

30. Lin Q, Deslouches B, Montelaro RC, Di YP. Prevention of ESKAPE pathogen biofilm formation by antimicrobial peptides WLBU2 and LL37. Int J Antimicrob Agents. 2018;52:667-672.

31. Swedan S, Shubair Z, Almaaytah A. Synergism of cationic antimicrobial peptide WLBU2 with antibacterial agents against biofilms of multi-drug resistant Acinetobacter baumannii and Klebsiella pneumoniae. Infect Drug Resist. 2019;12:2019-2030.

32. Deslouches B, Clancy C, Nguyen M, Cheng S, Mietzner T. The antimicrobial peptide Wlbu2 is active against candida spp., Cryptococcus neoformans and Leading Causes of Bacterial Sepsis. 2008.

33. Chen C, Deslouches B, Montelaro RC, Di YP. Enhanced efficacy of the engineered antimicrobial peptide WLBU2 via direct airway delivery in a murine model of Pseudomonas aeruginosa pneumonia. Clin Microbiol Infect. 2018;24:547.e1-547.e8

34. Lashua LP, Melvin JA, Deslouches B, Pilewski JM, Montelaro RC Bomberger JM. Engineered cationic antimicrobial peptide (eCAP) prevents Pseudomonas aeruginosa biofilm growth on airway epithelial cells. J Antimicrob Chemother. 2016;71:2200-2207.

35. Paranjape SM, Lauer TW, Montelaro RC, Mietzner TA, Vij N. Modulation of proinflammatory activity by the engineered cationic antimicrobial peptide WLBU-2. F1000Res. 2013;2:36.

36. Deslouches B, Steckbeck JD, Craigo JK, Doi Y, Burns JL, Montelaro $R C$. Engineered cationic antimicrobial peptides to overcome multidrug resistance by ESKAPE pathogens. Antimicrob Agents Chemother. 2015:59:1329-1333.

37. Mandell JB, Deslouches B, Montelaro RC, Shanks RMQ, Doi $Y$, Urish $K L$. Elimination of antibiotic resistant surgical implant biofilms using an engineered cationic amphipathic peptide WLBU2. Scientific Reports. 2017;7:18098.

38. Tripathi K. Essentials of Medical Pharmacology. $7^{\text {th }}$ ed. New Delhi, India: Jaypee Brothers Medical Publishers; 2013.

39. Mohamed MF, Hamed MI, Panitch A, Seleem MN. Targeting methicillinresistant Staphylococcus aureus with short salt-resistant synthetic peptides. Antimicrob Agents Chemother. 2014:58:4113-4122.

40. Biggin PC, Sansom MS. Interactions of alpha-helices with lipid bilayers: a review of simulation studies. Biophys Chem. 1999;76:161-183.

41. Chu HL, Yu HY, Yip BS, Chih YH, Liang CW, Cheng HT, Cheng JW. Boosting salt resistance of short antimicrobial peptides. Antimicrob Agents Chemother. 2013;57:4050-4052.

42. Turner J, Cho Y, Dinh NN, Waring AJ, Lehrer Rl. Activities of LL-37, a cathelin-associated antimicrobial peptide of human neutrophils. Antimicrob Agents Chemother. 1998;42:2206-2214. 
43. Mohamed MF, Brezden A, Mohammad H, Chmielewski J, Seleem MN. A short D-enantiomeric antimicrobial peptide with potent immunomodulatory and antibiofilm activity against multidrug-resistant Pseudomonas aeruginosa and Acinetobacter baumannii. Sci Rep. 2017;7:6953.

44. Kim MK, Kang HK, Ko SJ, Hong MJ, Bang JK, Seo CH, Park Y. Mechanisms driving the antibacterial and antibiofilm properties of Hp1404 and its analogue peptides against multidrug-resistant Pseudomonas aeruginosa. Sci Rep. 2018;8:1763.

45. Mohamed MF, Abdelkhalek A, Seleem MN. Evaluation of short synthetic antimicrobial peptides for treatment of drug-resistant and intracellular Staphylococcus aureus. Sci Rep. 2016;6:29707.

46. Galdiero E, Lombardi L, Falanga A, Libralato G, Guida M, Carotenuto R. Biofilms: novel strategies based on antimicrobial peptides. Pharmaceutics. 2019;11:322.

47. Ciandrini E, Morroni G, Arzeni D, Kamysz W, Neubauer D, Kamysz E, Cirioni O, Brescini L, Baffone W, Campana R. Antimicrobial activity of different antimicrobial peptides (AMPs) against clinical methicillinresistant Staphylococcus aureus (MRSA). Curr Top Med Chem. 2018;18:2116-2126.

48. Rishi P, Vij S, Maurya IK, Kaur UJ, Bharati S, Tewari R. Peptides as adjuvants for ampicillin and oxacillin against methicillin-resistant Staphylococcus aureus (MRSA). Microb Pathog. 2018;124:11-20.
49. Pletzer D, Mansour SC, Hancock REW. Synergy between conventional antibiotics and anti-biofilm peptides in a murine, sub-cutaneous abscess model caused by recalcitrant ESKAPE pathogens. PLoS Pathog. 2018;14:e1007084.

50. Gopal R, Kim YG, Lee JH, Lee SK, Chae JD, Son BK, Seo CH, Park Y. Synergistic effects and antibiofilm properties of chimeric peptides against multidrug-resistant Acinetobacter baumannii strains. Antimicrob Agents Chemother. 2014;58:1622-1629.

51. Wu X, Li Z, Li X, Tian Y, Fan Y, Yu C, Zhou B, Liu Y, Xiang R, Yang L. Synergistic effects of antimicrobial peptide DP7 combined with antibiotics against multidrug-resistant bacteria. Drug Des Devel Ther. 2017;11:939-946

52. Corbett D, Wise A, Langley $T$, Skinner K, Trimby E, Birchall S, Dorali A, Sandiford S, Williams J, Warn P, Vaara M, Lister T. Potentiation of antibiotic activity by a novel cationic peptide: potency and spectrum of activity of SPR741. Antimicrob Agents Chemother. 2017;61:e00200-e00217.

53. Flamm RK, Rhomberg PR, Simpson KM, Farrell DJ, Sader HS, Jones RN. In vitro spectrum of pexiganan activity when tested against pathogens from diabetic foot infections and with selected resistance mechanisms. Antimicrob Agents Chemother. 2015;59:1751-1754.

54. Tyers M, Wright GD. Drug combinations: a strategy to extend the life of antibiotics in the $21^{\text {st }}$ century. Nature Rev Microbiol. 2019;17:141-155. 